\title{
An application of AHP method for ranking administrative headquarters of the state welfare in Iran
}

\author{
Mohammad Hakkak*
}

Assistant Professor, Management Department, Lorestan University, Khoram Abad, Iran

\begin{tabular}{l}
\hline C H R O N I C L E \\
\hline Article history: \\
Received February 15, 2013 \\
Received in revised format \\
3 May 2013 \\
Accepted May 42013 \\
Available online \\
May 72013 \\
\hline Keywords: \\
State welfare organization \\
Priority Change the administrative \\
system \\
Analytical hierarchy processes
\end{tabular}

\section{A B S T R A C T}

\begin{abstract}
The purpose of the present study is to prioritized different methods for making necessary change on the administrative system of the central state Welfare Organization in Iran. The proposed model of this paper uses descriptive and measuring approach based on 11 questionnaires, which include criteria and necessary options to change the administrative system. The proposed model selects the sample size from different management levels, human capital development assistance, top, middle, and operational mangers of central state Welfare organization. Analytical hierarchy process (AHP) technique is used to perform pairwise comparisons and Expert Choice is implemented to analyze the information. The results indicate that structure and process correction are the primary requirements for systematic changing. Weight of mentioned index is 0.203 and the Compatibility Rating of changing criterion is equal to 0.06 .
\end{abstract}

\section{Introduction}

Understanding different circumstances of carrying out the changes in the administrative system of bureaucracy play important role on making managerial decisions. According to Aslan et al. (2011), one of the primary assumptions on adequateness is strategic leadership and acting strategic represents for a competent of leadership in various theories and hypotheses. During the past few hours, there have been tremendous efforts on using leadership and finding necessary factors for making changes. Aslan et al. (2011), for instance, performed an investigation on three dimensions of strategic leadership and investigated the strategic leadership fact of SMEs in Konya province of Turkey industrial zone. Jablonsky (2007) presented some models for making an assessment on efficiency of production units. The standard modeling technique for the evaluation of efficiency was based on data envelopment analysis (DEA) on the definition of efficiency as the ratio of outputs produced by the unit and inputs spent in the production process. Biberman and Whitty (1997) explored on some principles, which could be applied to produce power in organizational settings. Lijuan and Shinan 
(2011) presented an approach based on analytical hierarchy process (AHP) (Saaty, 1996, Saaty, 2006) for human factors analysis in the aircraft icing accident and provided reliable basis for equipment improvement and personnel management. Zhang and Zhou (2008) provided an application based on various multi criteria decision making approach in evaluating sequence of Air Target Threat. Penbek et al. (2011) investigated on the need for effective strategic management during a planned change based on an example of bologna change process from a Turkish university. They investigated the road map, pitfalls experienced, role and readiness of internal stakeholders involved in a planned organizational change and reported that effective strategic management should be agile to help firms move quickly in response to new environmental changes, and replaced outdated ideas and applications with processes, which could provide to meet new requirements as they present themselves. Wu et al. (2011) performed an investigation on evaluating growth suitability of Carya Cathayensis Sarg. based on principal component analysis (PCA) and AHP (Saaty \& Vargas, 1994). They selected 8 indexes including elevation, slope, aspect, surface curvature, humidity index, solar radiation index, soil types, and soil textures to evaluate the growth suitability of Carya Cathayensis Sarg. Sofiyabadi et al. (2012) presented an integrated balanced score card combined with DEMATEL technique to prioritize different alternatives for supply chain implementation.

\section{The proposed study}

The proposed study of this paper tries to find priority criteria associated with welfare reform in headquarter offices. Therefore, the main question of this survey is as follows,

Main question: How priority criteria Welfare reform in the headquarters office looks like?

There are ten secondary research questions considered as follows,

1. What are the priority criteria for the deployment of e-government development?

2. What factors do they change the priority criteria for justice, employment and payment system?

3. What priority criteria do they influence on Regulatory Human evolution?

4. What are the necessary changes for decentralization?

5. What are the priority criteria in terms of efficiency and the development of a comprehensive performance management system?

6. What is the priority for health administration standards based development?

7. Which priority measures can be used to improve the structures and processes of changes?

8. What are the priority criteria for empowerment, education and cultural development of human resources expertise?

9. Which important criteria do they influence the most on management strength to have more control on organization?

10. What are the priority changes on services provided to people and with respect to them?

\subsection{Conceptual model of research}

This research model has three components as follows:

The primary goal is to prioritize the development of the Welfare State organization of Iran the administrative headquarters and the proposed model measures changes in the administrative system based on ten main programs. The model is derived from the following options for each of the ten 
programs' standards development in administrative system. Fig. 1. Shows different levels of the proposed model.

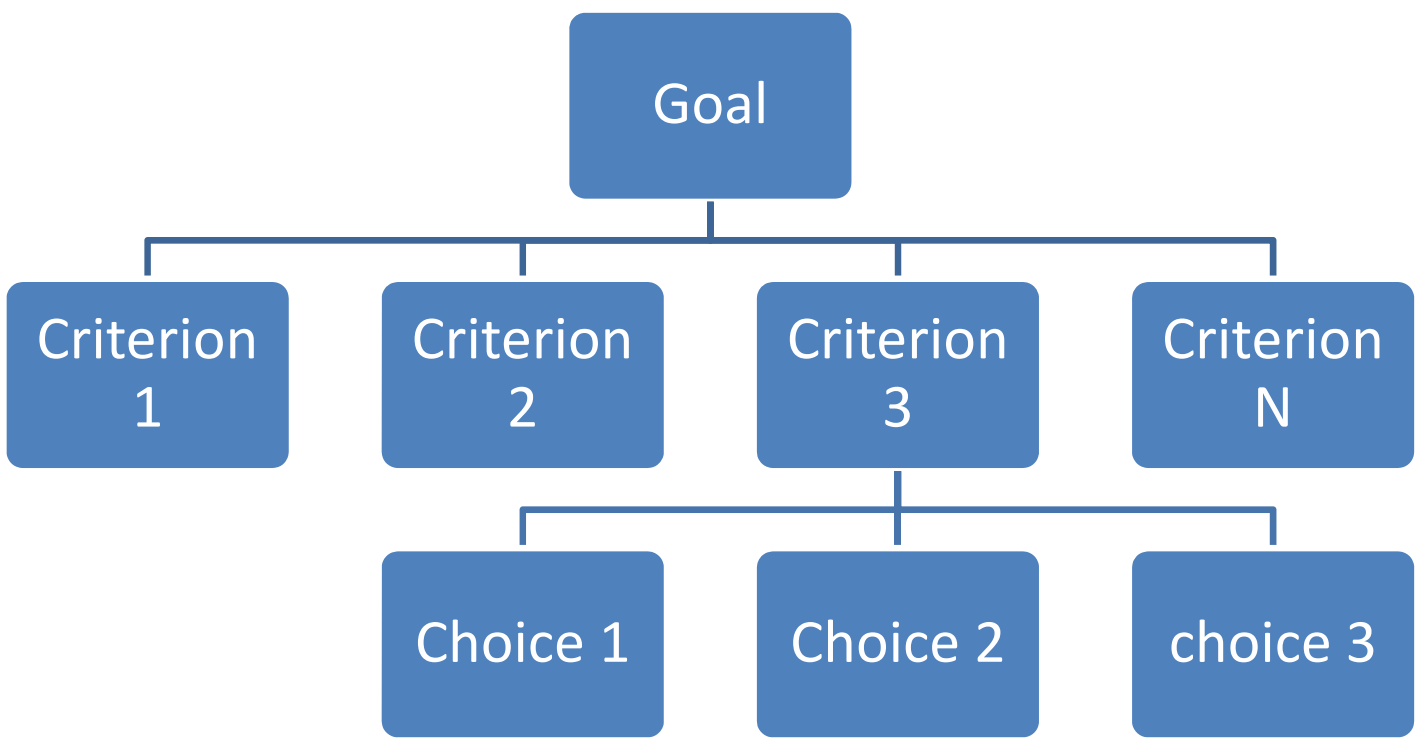

Fig. 1. The structure of the proposed model

\subsection{Methodology}

This research is applicable from goal type point of view and it is qualitative from qualitative point of view. Nature of method is executed in terms of descriptive and measuring form. Statistical community includes all 101 managers at different levels of organization in three categories of highlevel executives, mid-level and operational headquarters in welfare state organization of Iran. Sampling method is stratified relative and sample size formula is based on Cochrane systematic sampling data collected from 60 people, randomly. Since the inconsistency rate is less than or equal to 0.1 , the reliability of the results obtained is confirmed and the ranking have been completed via Expert choice software and hierarchical analysis is used to prioritize key factors.

\section{Results}

In this section, we present details of our pairwise comparisons associated with various criteria. Table 1 demonstrates the results based on objective measures of changes in the administrative system

\section{Table 1}

Results of pair-wise comparison based on the objective of measuring the changes in the administrative system

\begin{tabular}{lll}
\hline & Priority & Option \\
\hline 1 & Structure and reforming process & 0.203 \\
2 & Increase productivity and establishment of a comprehensive system of performance management & 0.154 \\
3 & Empowerment and cultural education and specialized human resources & 0.146 \\
4 & Strengthen management and improve their morale and ability to master the control tasks & 0.136 \\
5 & Decentralization & 0.096 \\
6 & The Pay and Employment Equity & 0.076 \\
7 & Organized labor & 0.060 \\
8 & The establishment of e-government & 0.052 \\
9 & Public service and respect for individuals & 0.044 \\
10 & Health Administration & 0.033 \\
\hline Consistency ratio $=0.06<0.1$ &
\end{tabular}

As we can observe from the results of Table 1, "structure and reforming process" is number one priority followed by "Increase productivity and establishment of a comprehensive system of 
performance management" and "Empowerment and cultural education and specialized human resources". The consistency ratio has been calculated as 0.06 , which is less than 0.1 and the results are valid. Table 2 summarizes the results of pairwise comparison for transformation options.

Table 2

The summary of pairwise comparison for transformation options

\begin{tabular}{lll}
\hline & Priority & Option \\
\hline 1 & Providing necessary information services & 0.561 \\
2 & Two-way communication and interaction with people and the state government & 0.251 \\
3 & Performance evaluation processes and systems provider & 0.116 \\
4 & People Complaints & 0.072 \\
\hline Consistency ratio $=0.07<0.1$ &
\end{tabular}

The results of Table 2 indicate that "information services" plays the most important role followed by two-way communication and interaction with people and the state government. The consistency ratio is again less than 0.1 , which validates the results of our survey. Organized labor is the next criteria and Table 3 summarizes the results of pairwise comparison.

\section{Table 3}

Results of pair-wise comparison organized labor

\begin{tabular}{lll}
\hline & Priority & Option \\
\hline 1 & Establishment of teleworking & 0.285 \\
2 & Outsourcing & 0.178 \\
3 & Transfer to state sector with government jobs & 0.142 \\
4 & Supporting private sector & 0.106 \\
5 & Giving priority to the affairs of state enterprises into cooperatives & 0.075 \\
6 & The officer on duty in the state sector & 0.071 \\
7 & Personnel transferring to the private sector & 0.053 \\
8 & Agree with unpaid leave & 0.049 \\
9 & Public service and respect for individuals & 0.044 \\
10 & Redeeming years of being employee & 0.040 \\
\hline Consistency ratio $=0.06<0.1$ &
\end{tabular}

The results of Table 3 clearly indicates that establishment of teleworking is number one priority followed by outsourcing some of responsibilities and transfer to state sector with government jobs.

\section{Table 4}

The summary of pairwise comparison for criteria associated with efficiency

\begin{tabular}{lll}
\hline & Priority & Option \\
\hline 1 & $\begin{array}{l}\text { Carrying out article } 82 \text { of the law on civil service management, performance management systems at all } \\
\text { levels of administration }\end{array}$ & 0.599 \\
2 & Determining targeted and result-oriented criteria and standards for quality of service & 0.231 \\
3 & Determining the cost of activities and services & 0.113 \\
4 & Determining the status and progress of the country compared to other countries & 0.057 \\
\hline Consistency ratio $=0.09<0.1$
\end{tabular}

The results of Table 4 show that in terms of efficiency, applying article 82 of the law on civil service management and performance management system at all levels of administration is the most important task, which must be accomplished.

\section{Table 5}

The summary of pairwise comparison for transformation options

\begin{tabular}{lll}
\hline & Priority & Option \\
\hline 1 & $\begin{array}{l}\text { Strengthening pay attention to the rule of law and accountability to the public similar respect to their } \\
\text { clients }\end{array}$ & 0.644 \\
2 & $\begin{array}{l}\text { Exert control and maintain healthy relationships and avoid the expense of employee conduct and duties } \\
\text { of state and treasury losses }\end{array}$ & 0.243 \\
$3 \quad \begin{array}{l}\text { Encounter with real persons bribes to employees of the executive and submitted the case to the judicial } \\
\text { authorities }\end{array}$ & 0.113 \\
\hline Consistency ratio $=0.08<0.1$ &
\end{tabular}


Table 6

The summary of pairwise comparison for criteria associated with transformation options

\begin{tabular}{lll}
\hline & Priority & Option \\
\hline 1 & To organize, design and setting up the structure of executive & 0.497 \\
2 & Revise comprehensive structure of executive & 0.297 \\
3 & Improved processes and methods of work with automation approach & 0.147 \\
4 & Shortening procedures and bureaucratic hierarchy in the vertical and horizontal management & 0.059 \\
\hline Consistency ratio $=0.07<0.1$
\end{tabular}

The results of Table 6 clearly show that organization, design and appropriate structure of executives is the most important criterion in transformation options. Next, we present details of pairwise comparison on criteria associated with empowerment and cultural education.

\section{Table 7}

The summary of pairwise comparison for criteria associated with empowerment and cultural education

\begin{tabular}{lll}
\hline & Priority & Option \\
\hline 1 & $\begin{array}{l}\text { Proportionate knowledge, skills and attitudes of government employees on the job in the new education } \\
\text { system }\end{array}$ & 0.449 \\
2 & $\begin{array}{l}\text { Presenting cultural training to managers and experts } \\
3\end{array} \quad \begin{array}{l}\text { Establish communication between employees and management to improve the education and benefit of } \\
\text { its privileges }\end{array}$ & 0.338 \\
$4 \quad$ Organizing by domestic and foreign scholarships and training for government employees & 0.121 \\
\hline Consistency ratio $=0.02<0.1$ & 097 \\
\hline
\end{tabular}

\section{Table 8}

Results of pair-wise comparison for strengthen management options based on criteria

\begin{tabular}{lll}
\hline & Priority & Option \\
\hline 1 & $\begin{array}{l}\text { Create mechanisms for employee participation and benefit from their ideas and creativity in decision- } \\
\text { making }\end{array}$ & 0.392 \\
2 & $\begin{array}{l}\text { Train efficient, useful, valuable and establish merit-based and make stability in managers services } \\
\text { To grant authority to the directors to apply management units covered by the volume of activities and } \\
\text { services cost }\end{array}$ & 0.260 \\
0.167 & 0.105 \\
4 & $\begin{array}{l}\text { Creating and maintaining database managers and human resources to identify qualified individuals } \\
\text { (Article 55 Law on Civil Service Management) }\end{array}$ & 0.075 \\
5 & $\begin{array}{l}\text { To use the service, academia, education, research, public and private institutions have been approved to } \\
\text { perform services }\end{array}$ & \\
\hline Consistency ratio $=0.05<0.1$
\end{tabular}

The results of Table 8 clearly indicate that employee participation and benefit from their ideas and creativity in decision-making is the number of priority in our system. The consistency ratio is 0.05 , which is well below the minimum acceptable limit.

\section{Table 9}

The summary of pairwise comparison for the criteria of services

\begin{tabular}{lll}
\hline & Priority & Option \\
\hline 1 & Familiarize People with their rights and duties in order to use the services of executive & 0.563 \\
2 & The standardized services provided to people & 0.260 \\
3 & $\begin{array}{l}\text { Assess the impact of satisfaction and dissatisfaction with the performance of employees and managers in } \\
\text { the promotion and appointment }\end{array}$ & 0.177 \\
\hline Consistency ratio $=0.06<0.1$ &
\end{tabular}

The highest priority items was allocated to measure of e-government, which is "options and created databases and information services" with a relative weight of 0.561 and the numbers are consistent since the consistency ratio was calculated as 0.07 . In terms of payment options, standards and job attractions are another important criterion with the relative importance of 0.464 . 


\section{Conclusion and recommendations}

By studying the actions taken by countries like Malaysia, Argentina, and Poland in the field of administrative reform we understand that these countries do their reforms in laws, administrative structure, management, technology, corporate policies and procedures and the staff and priority programs. By examining research on administrative change in Iran, we understand that there was a need to comply with the order and priority programs and if there were not any respect for transposition, it would not be possible to run a successful program. Our priority include structural factors such as infrastructure and administrative reform, the performance indicators and productivity, workforce empowerment, and strengthening the management. Therefore, we recommend the government to privatize and transfer the affairs to non-governmental and people with according to Article 44 of constitution and Article 24 of the Civil Service Management as a standalone application. Government must sub contract privatization programs and transfer all affairs to the people and nongovernmental parts, including programs like preparing field to enter private parts, the security investment, taxation and grant better protection for the nongovernmental sector. Government also must convert employment equity program and payment system as two independent and separate employment equity programs and compensation system.

\section{References}

Aslan, Ş., Diken, A., \& Şendoğdu, A. A. (2011). Investigation of the Effects of Strategic Leadership on Strategic Change and Innovativeness of SMEs in a Perceived Environmental Uncertainity. Procedia-Social and Behavioral Sciences, 24, 627-642.

Biberman, J., \& Whitty, M. (1997). A postmodern spiritual future for work. Journal of organizational change management, 10(2), 130-138.

Jablonsky, J. (2007). Measuring the efficiency of production units by AHP models. Mathematical and Computer Modelling, 46(7), 1091-1098.

Lijuan, C., \& Shinan, C. (2011). An approach of AHP for human factors analysis in the aircraft icing accident. Procedia engineering, 17, 63-69.

Penbek, Ş., Zaptçıoğlu, D., \& Günerergin, M. (2011). The need of effective strategic management during a planned change: An example of bologna change process from a Turkish university. Procedia-Social and Behavioral Sciences,24, 649-662.

Saaty,T.L. (2006). Rank from comparisons and from rating in the analytic hierarchy/network. European Journal of Operational Research, 168, 557-570.

Saaty, T. L. \& Vargas, L. (1994) Decision making with analytic hierarchy process. RWS.

Saaty,T. L. (1996). The analytic hierarchy process. RWS.

Sofiyabadi, J., Movahedi, M \& Nasab, S. (2012). Strategic orientation in evaluation of supply chain activities. Management Science Letters , 2(5), 1785-1794.

Wu, D. S., Feng, X., \& Wen, Q. Q. (2011). The research of evaluation for growth suitability of Carya Cathayensis Sarg. based on PCA and AHP. Procedia Engineering, 15, 1879-1883.

Zhang, K., \& Zhou, D. Y. (2008). Application of TOPSIS based on Entropy and GD-AHP in evaluating sequence of Air Target threat. Journal of System Simulation, 7, 004. 